Article

\title{
Learning from the Experiences of the Intergovernmental Panel on Climate Change: Balancing Science and Policy to Enable Trustworthy Knowledge
}

\author{
Karin M. Gustafsson \\ Environmental Sociology Section, School of Humanities, Education and Social Sciences, Örebro University, \\ SE-701 82 Örebro, Sweden; karin.m.gustafsson@oru.se; Tel.: +46-19-31-3084
}

Received: 11 October 2019; Accepted: 18 November 2019; Published: 20 November 2019

check for updates

\begin{abstract}
To create a societal change towards a sustainable future, constructive relations between science and policy are of major importance. Boundary organizations such as the Intergovernmental Panel on Climate Change (IPCC) have come to play an important role in establishing such constructive relations. This study contributes to the development of empirically informed knowledge on the challenge of balancing different expectations for how the science-policy relation is to be constructed to create trustworthy knowledge and policy decisions, i.e., when to be what and to whom. This study revisits Climategate and uses the public debate on the IPCC's credibility, legitimacy, and policy relevance that followed Climategate as an analytical window to explore how the IPCC balanced the science-policy relation in a trustworthy manner. The analysis is based on a document study. The study shows how different expectations on the science-policy relation coexist, and how these risks create a loss of trust, credibility, legitimacy, and policy relevance. Thus, for boundary organizations to have a chance to impact policy discussions, reflexivity about the present epistemic ideals and expectations on knowledge production is of major importance, and must be reflected in an organizational flexibility that is open to different strategies on how to connect science and policy in relation to different actors and phases of the knowledge production process.
\end{abstract}

Keywords: science-policy interface; IPCC; Climategate; boundary organization; landscape of tension; stage-management

\section{Introduction}

To create a societal change towards a sustainable future, constructive relations between science and policy are of major importance. However, due to the dominating understanding in society that science and policy are guided by different internal logics (science by objective knowledge, and policy by subjective values), it is difficult to determine what such a constructive relation entails and how to make that relation a reality [1,2]. Instead, due to their differences, any relation between science and policy risks jeopardizing the legitimacy of both practices [3,4]. For example, actions to strengthen the relation's scientific credibility could weaken its policy relevance, and efforts to enhance the relation's relevance could risk harming its legitimacy [4]. Thus, for the relation to be constructive, multiple expectations from both science and policy, as well as tradeoffs between these expectations, must be balanced [4-8]. Parker and Crona describe this challenge as "an ongoing process of negotiating the multiple tensions that arise from divergent stakeholder demands. / $-/$ [Thus,] effective boundary management is about knowing when to be what and to whom" [8] (pp. 282, 285).

Parker and Crona [8] identify how tensions create a social landscape within which organizations situated at the boundary between science and policy navigate multiple and shifting expectations and 
power relations in their ambition to create constructive and efficient science-policy relations. Their idea of the landscape of tensions creates a theoretical explanation of what it means to balance when to be what and to whom ([8], cf. civic epistemologies in Jasanoff [9], and Lidskog and Sundqvist [10]). At the same time, the theory emphasizes the fact that every situation is unique in how it plays out and what needs to be done to become a credible and trustworthy organization. Thus, there is not one solution for the challenge of creating a constructive science-policy relation. Instead, the challenge must be met with reflexivity and flexibility by drawing on both empirical experiences and theoretical knowledge.

The relation between science and policy has been subjected to comprehensive empirical studies and in-depth theoretical discussions (e.g., [3,4,11-13]). However, the dynamic aspect of what it means to create constructive science-policy relations, identified by Parker and Crona [8] and captured in the question of when to be what and to whom, still lacks deeper empirical study and theoretical exploration. The current study aims to address this knowledge gap through an empirical focus on the most well-known organization at the boundary between science and policy-the Intergovernmental Panel on Climate Change (IPCC) - and through a theoretical interest in how the IPCC faced and managed the science-policy relation during one of its greatest challenges yet: Climategate.

Climategate refers to the now well-known series of events that started when thousands of files that were illegally obtained from servers at the Climatic Research Unit at the University of East Anglia, UK were published on the internet in November 2009 [14,15]. The Climategate files included documents, raw data, computer code, and e-mail correspondence between high-profile climate scientists [14]. Together, the files showed the scientific research process that proceeded with highly profiled results published in scientific articles and communicated publicly to explain climate change. The following month, Climategate took an additional direction by the unveiling of errors in the IPCC's fourth assessment report (AR4) [16]. Two of these errors came to dominate the discussion about the credibility of the IPCC: First, the IPCC's prediction of the melting rate of the Himalayan glaciers, and second, its report of the size of the Netherlands' land area below sea level [17-21]. A heterogeneous group of climate skeptics and other critical actors effectively made the Climategate files and the errors in AR4 subject to a public debate about the credibility and trustworthiness of climate science in general and the IPCC in particular [20,22]. These critics varied from actors arguing that the files and errors were proof that the claim of anthropogenic climate changes was an alarmistic hoax [15], to actors arguing that the files and errors should be seen as signs that climate science and the IPCC needed to engage in self-critique and improve their work methods to remain trustworthy [19].

The criticism raised through Climategate, including that of the IPCC's AR4, resulted in the IPCC becoming involuntarily involved in a public debate on its assessment reports' credibility and legitimacy [23]. In retrospect, this debate opened an analytical window into the IPCC's ideas about how to produce trustworthy knowledge. Thus, the objective of this study is to take advantage of this analytical window to elaborate on the theoretical understanding of the challenges that come with trying to repair an expert organization's credibility and science-policy relation.

The analysis herein is based on a document study. The selection of relevant documents for the study was performed by following discussions and arguments related to Climategate and the criticism of the IPCC's AR4. The selection process started in the scientific literature on Climategate, which served as a departure point for a wider search for nonscientific documents of relevance to the study. The selection process resulted in a combination of primary and secondary material on Climategate and the criticism of the IPCC's AR4. The primary material consists of official IPCC documents and assessment reports that review the work done by the IPCC, while the secondary material consists of scientific studies as well as gray literature on Climategate and the IPCC. As a response to Climategate, two external reviews of the IPCC were executed to improve the work of the organization (IAC 2010; PBL 2010). Guided by the theoretical framework presented below, the document material was analyzed in two steps. In the first step, the analysis explored ideas and expectations on how to balance the science-policy relation among the involved main actors: The critics, the reviewers, and the IPCC itself. In the second step, the analysis explored how these ideas related to and influenced the IPCC's way 
of managing the science-policy relation throughout Climategate and in its aftermath. Through its analysis, the current study adds new knowledge on how different, sometimes conflicting, ideas of how to produce trustworthy, credible, legitimate, and policy-relevant knowledge coexist, interact, and influence when to be what and to whom.

The paper is organized as follows. Section 2 presents the IPCC and Climategate and further specifies the aim of the study. Section 3 elaborates on the study's theoretical framework regarding how the science-policy relation could be understood and explained as either a linear or collaborative relation that is established and maintained in a complex landscape of tensions. Section 4 revisits the events of Climategate and analyzes how the IPCC and two external reviews in relation to Climategate argued about how to balance science and policy to make the IPCC a trustworthy and credible organization, and how these arguments relate to one another. Section 5 presents the analysis conclusions and comments on what it means that different and sometimes conflicting ideas of how to produce trustworthy, credible, legitimate, and policy-relevant knowledge coexist.

\section{The IPCC and Climategate}

The IPCC was founded in 1988 to provide policy-relevant but not policy-prescriptive knowledge assessments on the current state of knowledge on climate change and its potential environmental and socioeconomic impacts [24]. The organization is open for membership to all states in the United Nations (UN). In 2019, the IPCC had 195 member states [25] and coordinated nearly a thousand of the world's leading climate scientists in their work to produce the IPCC's sixth assessment report and three special reports. Through its method of organization, the IPCC could be described as a science-policy interface [7], a boundary organization enabling collaboration across the science-policy boundary [26], or even "an oxymoron [as it is providing] quality scientific assessments by democratic consensus" [24] (p. 1). Thus, on a daily basis for over 30 years, the IPCC has faced the challenge of navigating between science and policy to produce credible and policy-relevant knowledge. As a result of this balancing act, the IPCC has become the epistemic authority on climate change.

In recent years, the IPCC has been the object of many studies that have explored science-policy relations. For example, the IPCC has been studied in terms of its history [24,27], its relation to nation states [28], its status as a boundary organization [26,29], and the way that it coproduces knowledge and social order [30,31]. The IPCC has further been studied to answer questions about how epistemological assumptions structure expert organizations, and how these assumptions influence the extent to which expert organizations are seen as credible, relevant, and legitimate [4,5,7,13,32].

IPCC assessments have been criticized for having several biases, such as geographical bias concerning the representation of scientists in favor of the global north [33], gender bias in favor of men [34], disciplinary bias in favor of the natural sciences over social sciences, humanities, and indigenous knowledge [35-37], and a prioritization of scientific credibility at the expense of relevance and legitimacy $[4,38]$. Taken together, there are conflicting views of the extent to which the IPCC's efforts to create credible assessments should be deemed successful [12,39-41]. Nevertheless, it has been shown that the IPCC has played an important role leading up to many meetings of the Conference of the Parties (COP) within the United Nations Framework Convention on Climate Change (UNFCCC), not least in the preparations for the 21st COP meeting in Paris in December 2015 [42].

In 2007, the IPCC was jointly awarded the Nobel Peace Prize together with Albert "Al" Gore Jr. "for their efforts to build up and disseminate greater knowledge about man-made climate change and to lay the foundations for the measures that are needed to counteract such change" [43]. The prize served to confirm the trustworthiness and credibility of the IPCC and made the IPCC's work known to a broader public. However, gaining trust and credibility is an ongoing and relational process [44,45]. Trust and credibility are gained and can be lost, a fact that became a reality for the IPCC when Climategate broke in 2009 [17,20,23,46,47].

The IPCC was not the main character within the pages of the Climategate files, and thus was not the primary target of the criticism of Climategate. However, through guilt by association, Climategate 
came to cast a shadow of doubt over the credibility and trustworthiness of the IPCC [14,17,22,48,49]. This outcome occurred since the criticized climate scientists played an active role in the IPCC's assessment process, and their scientific results were central contributions to the IPCC's assessment reports [20]. As if this close association to the Climategate files was not enough for the IPCC to face while protecting its reputation as a trustworthy organization, its credibility took another hit as the turbulence of Climategate grew in the months that followed, especially when it was discovered that there were several errors in the IPCC's AR4 [16]. The errors in AR4-the incorrect prediction of the melting rate of the Himalayan glaciers, and the report of the size of the Netherlands' land area below sea level-forced the IPCC to publicly shift their focus from communicating the results in the assessment report to explaining how the errors could have happened; these explanations also needed to simultaneously validate the IPCC's assessment process in general. The IPCC's institutional position at the boundary between science and policy and as a link to the UN was no longer enough to guarantee the quality of the assessment report, and the assessment process was no longer solely an internal affair for the IPCC but instead a prerequisite for external actors to determine if the IPCC could be trusted or not.

In the aftermath of Climategate, including the criticism of the IPCC's AR4, multiple studies were performed on how the IPCC managed and was affected by the situation. The studies showed how Climategate contributed to the continuing polarization between climate science on one hand and climate skeptics on the other, and how Climategate resulted in the IPCC suffering a loss of trust as their credibility as knowledge producers was questioned (e.g., $[14,17,22,48,49])$. Despite this crisis and the polarizing tendencies, the IPCC has once again strengthened its position as a knowledge producer and has continued to play an important role as an indirect contributor to policy processes and decision making, such as the Paris Agreement in 2015 (e.g., [42]).

\section{Theoretical Perspective}

IPCC is a boundary organization, i.e., an organization that enables collaboration between the social practices of science and policy [26]. A boundary organization is characterized by functioning as a science-policy interface where the organization is able to coordinate work and transfer knowledge between the two social practices on topics that are of common interest to both [50-52]. The development of the boundary organization concept has called into question the description of the science-policy relation as that of a linear relation with clear boundaries between science and policy, which in large parts of society holds a dominant position as an ideal of how science and policy are to be related (e.g., [12]). Instead, the boundary organization concept helps open up an idea of a collaborative science-policy relation in which knowledge and policy decisions are understood as being created through a co-production process involving both science and policy $[8,41,53,54]$.

The idea that the relation between science and policy is best described and should be organized as a linear relation is based on the understanding of science and policy as two distinctly different social practices [11]. Science as a social practice is characterized by the search for objective knowledge, while policy as a social practice is characterized by value conflicts. Within this perspective, the relation between science and policy is understood as a strict division of labor where science provides and communicates facts, which policy may use to make informed decisions. For each practice to work at its best, their relation needs to be organized in a way that creates a clear boundary between them, allowing both science and policy to work independently from one another and create credible knowledge and policy decisions $[4,12]$. However, this linear description of the science-policy relation has received strong criticism for not being descriptively accurate or normatively desirable (see, e.g., [11]). The boundary organization concept could be seen as a part of this critique and as a contribution to the development of an alternative collaborative perspective on the science-policy relation.

The idea that the science-policy relation is a collaborative relation is based on the understanding of science and policy as two social practices that together contribute to the production of knowledge and the creation of societal change $[10,55,56]$. Within this perspective, a clear boundary between 
science and policy is understood as being descriptively inaccurate, impossible, and undesirable [11]. Instead, science and policy are seen as codependent. The boundary between the two social practices is described as blurred, creating a hybrid space where knowledge gains not only epistemological credibility but also social robustness [53,57]. Thus, for the best outcome, the science-policy relation must be organized in a way that enables collaboration across the science-policy boundary, even in a manner that opens up the possibility of including other knowledge producers and stakeholders in the process when necessary $[8,32,55,58]$.

The normative ideals that guide an organization in how to constructively organize the science-policy relation do not necessarily coincide with how the same organization is described and understood, either internally by the organization itself or externally by the society or science. This difference between guiding ideals, self-understanding, and scientific descriptions is a recognition of the fact that sometimes a gap exists between the ideal towards which an organization is striving and how it is presently functioning [1]. Managing the boundary between science and policy is a process that stretches through time in a changing social landscape of expectations and power relations [8-10].

Parker and Crona describe the management of the boundary between science and policy as "a process of reconciling multiple tensions among the demands of stakeholders whose actions, expectations and orientations often defy [a] simplistic dichotomy" [8] (p. 282). They argue that creating a constructive and efficient science-policy relation is not a one-time decision on how to relate the two practices to one another, but is a constant process of negotiating and balancing these practices' conflicting expectations, such as if to produce either disciplinary or interdisciplinary knowledge based on either basic or applied research. Similarly, expectations on and ideals about how to organize the science-policy relation could differ between stakeholders as well as shift between different phases of knowledge production and over time because of changes in power relations. Hilgartner [59] describes these phases of knowledge production as well as changes in expectations and power relations by using dramaturgical concepts such as the backstage and the frontstage of science.

The science-policy relation is described by Hilgartner [59] as an ongoing performance in which behaviors differ depending on which social region it is being enacted (backstage or frontstage), the audience that is being addressed, and the present expectations on how science-policy relations make knowledge credible. The performance of science in the backstage region of what it means to conduct science differs in comparison to how science is performed and communicated in front of a policy audience (cf. the question of when to be what and to whom [8] and Latour's [60] distinction between research and science). The different regions consist of different combinations of actors who, by drawing on sometimes different ideals on what makes credible knowledge, engage in knowledge production. Thus, making the same knowledge claim credible over time and in the different phases of knowledge production requires different forms of stage and impression management. In this process, the boundary organization opens a space that allows for the inclusion of both frontstage and backstage activities to enable smooth transitions between the stages and to make the knowledge credible.

However, it is important to remember that the boundary organization concept is developed as a theoretical construct that is used by scientists to describe organizations situated at the boundary between science and policy [26]. This does not mean that all of these organizations themselves strive to establish a hybrid open space. Some of them do (see, e.g., [61,62]), but some of them do not (see, e.g., $[63,64])$. Instead, some of the organizations, defined by science as boundary organizations, are still intentionally organized based on the idea of a linear science-policy relation and a strict demarcation between the backstage and frontstage of scientific knowledge production. These organizations are used as mediating interfaces to secure a clear boundary between the social practices of science and policy [12].

In summation, a boundary organization such as the IPCC, which aims to produce credible and relevant knowledge for policy, must have an idea of how to organize the science-policy relation (cf. [1]). In what follows, this theoretical framework will be used to analyze how the IPCC balanced the relation between science and policy in the direct aftermath of Climategate. 


\section{Revisiting Climategate}

No one has been able to prove who illegally obtained and published the Climategate files in November 2009 [15]. Even so, when published, a heterogeneous group of climate skeptics and other critical actors effectively made the files subject to a public debate about the credibility of climate science [20,22]. By specifically referring to bits and pieces of the emails among the files, it was argued that the files were proof that the claim of anthropogenic climate change was an alarmistic hoax [15]. The emails covered a total of 13 years of formal, semiformal, and informal conversations between the world's leading climate scientists, including, e.g., discussions on methodological issues, open access to data, scientific communication, and relations to the public in general and climate skeptics in particular [20].

Multiple independent reviews were assigned to assess the credibility of the criticized scientists and their scientific results (e.g., the House of Commons, Science and Technology Select Committee [65], the Lord Oxburgh Science Assessment Panel [66], and the review by the US Environmental Protection Agency [67]). All the assessments reached a similar conclusion: That there had been no wrongdoing or misconduct as part of the research that produced the scientific results. Nothing was found that changed the scientific consensus that anthropogenic climate change is a fact. However, the reviewers concluded that there were problems with transparency in the data collection and data management, particularly at the Climatic Research Unit at the University of East Anglia (cf. [14,15,17]).

Similar to the initial argumentation surrounding Climategate, climate skeptics and other critical actors observed the errors in AR4 as signs that the IPCC was overly alarmistic in its predictions about climate change $[17,48]$. Some went as far as to say that the errors were a part of an intentional strategy to exclude critical perspectives from the IPCC, to wrongly enhance the arguments about the severity of current climate changes and to enhance the extent to which human activities are to blame for global warming [20]. However, even for the more modest critics, the errors still raised troubling questions about how they could have been included in the assessment and whether there were any additional undetected errors [19].

Two independent review assessments were assigned to audit the work of the IPCC and AR4. One was assigned by the IPCC and conducted by the InterAcademy Council $[68,69]$. The other one was assigned by the Dutch government and conducted by the Netherlands Environmental Assessment Agency (PBL) $[19,70]$. Neither assessment found any signs of significant errors or any results that had been tampered with. However, the PBL concluded that "in some instances, the foundations for the summary statements should have been made more transparent" [19] (p. 9), and the InterAcademy Council noted that "the IPCC must continue to adapt to [ . . ] ] changing conditions [i.e., greater overall scrutiny and demands from stakeholders] in order to continue serving society well in the future" [68] (p. xii).

Climategate, including the criticism of the IPCC's AR4, did not result in a changed understanding of the causes, character, and implications of climate change. Even so, the criticism resulted in an enlarged distrust towards climate experts among some stakeholders, policy actors, and the general public $[14,17,20,48,49]$. The IPCC's position as a trustworthy epistemological authority, a position that had previously been taken for granted, was questioned. Climategate placed the IPCC in a position in which it had to show that it was a trustworthy organization, and involuntarily, the IPCC became involved in a public debate on its credibility, legitimacy, and policy relevance [23]. The debate had two phases.

The first phase, as analyzed above, focused on the critics of IPCC and the legitimacy and relevance of their criticism. Using concepts outlined in the theoretical framework of this paper, the description of this phase could be summarized as that some of the audience members in the frontstage region of the IPCC's knowledge production raised a critique of the science-policy relations in the backstage regions of this process. This critique was based on factual errors that were argued to be signs of political bias in practices of knowledge production that was expected to be objective and value-neutral. The 
critique was addressed through multiple reviews of the backstage processes behind the identified errors, showing that these were the results of mistakes rather than a lack of objectivity and political bias.

The second phase of the public debate is analyzed in the section below, which focuses on the two main phase actors-the IPCC and the external reviewers-and their different arguments on how to balance science and policy to make the IPCC a trustworthy and credible organization. Starting with the perspective of the IPCC, the analysis will study both the perspectives and the relation between them.

\subsection{Balancing Science and Policy}

As an initial response to Climategate, the IPCC's chairman, Dr. Rajendra Kuma Pachauri, denied the existence of any errors in AR4 [13-15,17]. As a spokesperson for the IPCC, Pachauri argued that there was no reason for the IPCC to engage in any kind of self-critique about the organization's work [71]. Instead of acknowledging the errors found in AR4 and addressing how they could have passed undetected through the assessment process, Pachauri argued that the criticism was not based on science, but was to be understood as a political attack [17]. By responding in this manner, Pachauri tried to defend the credibility of the IPCC by drawing a boundary between science and policy and between the IPCC and the rest of society. In doing so, Pachauri interestingly drew on the same ideal of what makes good science as the one used by the critics, i.e., that science and politics should be kept separate. However, while the critics argued that the IPCC was being politically biased, Pachauri made the opposite argument, i.e., that the critique was to be seen as a political discussion in the frontstage region of how to understand and use scientific knowledge, rather than a valid scientific critique of the knowledge production performed backstage.

Instead of engaging with the opponents' criticism and the content of the critiqued knowledge claims, Pachauri's strategy was to reinforce the idea and expectation that credible, relevant, and legitimate knowledge is produced in social relations that could be described as clearly demarcated science-policy relations. Thus, indirectly, Pachauri argued for a linear science-policy relation in which science holds the position of speaking truth to power (cf. [17]). This position is not new to the IPCC. Quite the opposite, Pachauri acted in the (linear) knowledge tradition in which the IPCC was founded and developed (cf. $[24,27,32])$. Thus, even though the IPCC has the characteristic of being a boundary organization that creates a science-policy interface, the science-policy relation it upholds largely follows the logic of a linear knowledge tradition $[4,5,25,29]$.

Following the linear logic of science-policy relations, the IPCC's initial actions show clear disbelief that there could be a legitimate demand from actors in the IPCC audience that they be given access to the backstage practices of knowledge production to assess the credibility of the IPCC's process and results. The manifested idea is that credibility could only be determined through reviews performed backstage by peers, meaning actors holding a position within the scientific community or within the slightly extended review community of the IPCC system (cf. [72]). The argument is that the IPCC acts from a social position in which the organization should be seen as a trustworthy and credible organization on the merits that it is the climate field's primary expert organization. The sum of the backstage work of the IPCC's thousands of volunteer experts should be enough of a guarantee for the rest of society to trust the expert organization's work and assessments (cf. [72]). Thus, a lack of trust is seen by the IPCC as a failure in frontstage science communication, and not as a criticism of science or the organization per se. Following this argumentation, to regain trust and credibility, the IPCC needed to strengthen its (linear) relation to the rest of society through an improved communication strategy. Thus, question of when to be what and to whom, in terms of how to navigate the science-policy relation throughout the process of knowledge production (linearly or collaboratively) and who is to be involved in this knowledge production, was not up for negotiation. Instead, the assessment's high level of credibility, relevance, and legitimacy needed to be better translated and mediated to stakeholders, policy, and the public (cf. [17]). However, both reviews of the IPCC showed a social development that called into question the idea of science as holding a sovereign position that makes the IPCC trustworthy, credible, legitimate, and policy-relevant in and of itself. 
The reviews performed by the Netherlands Environmental Assessment Agency (PBL) [19] and the InterAcademy Council [68] of the IPCC and AR4 both highlighted transparency as one of the most important aspects in determining the credibility of AR4 and restoring trust in the IPCC's capacity to produce credible, relevant, and legitimate knowledge assessments (cf. [17,44]). In the PBL report [19], in addition to transparency in general, one of the major issues focused on is the role and transparency of expert judgments. With this focus, the PBL reviewed and addressed the main argument used by Pachauri to defend the IPCC and to argue for why the organization and AR4 are to be trusted: That the work of the IPCC is performed by the world's leading climate experts without political influence.

The PBL [19] agreed that expert judgments are central and important aspects of the assessment process. However, it also stated that "the quality of these assessments grows as the expert judgments are made more transparent, that is, by explaining how particular conclusions have been arrived at" [19] (p. 21). In this statement, we can see a shift from how the IPCC uses the experts as a reassurance for high credibility, relevance, and legitimacy per se to instead focusing on the experts as persons supposedly knowledgeable of how to execute the production of scientific knowledge assessments that result in credible, relevant, and legitimate knowledge. However, the issue of whether such knowledge is credible, relevant, and legitimate is always an empirical question. What is focused on by the PBL is the work of the actors and the collaborations throughout the backstage assessment process. Thus, what we see in the PBL review, in addition to a shift of focus from frontstage to backstage knowledge production and a blurring of the line that separates these regions, is a shift from a linear understanding of the science-policy relation to a collaborative one.

Similarly, the InterAcademy Council also began their report by agreeing with the IPCC's argument that experts are important. It stated that "the thousands of scientists and government representatives who work on behalf of the IPCC in this nontraditional partnership are the major strength of the organization" [68] (p. xii). Guided by their assignment [6] (p. xii), the InterAcademy Council went on to focus on the procedural and methodological aspects of the IPCC and the AR4 process. In their results, the InterAcademy Council ended up with a similar shift to the one discussed above in the analysis of the PBL report [19], that is, a shift from focusing on the sovereignty of science to emphasizing the importance of transparency in the IPCC's relations to the rest of society. The InterAcademy Council emphasized the IPCC's historical and current importance to climate science and climate policy. However, the InterAcademy Council also emphasized that the IPCC needed to adapt to current social conditions in which organizations are accountable to a growing number of interests and actors that all assess the credibility of IPCC's work and assessment reports.

To face criticism and adapt to the future, the InterAcademy Council recommended that the IPCC change its organization's governance and work processes to improve transparency. This shift within the InterAcademy Council's report is emphasized by Beck in her summary of their conclusion that "trust requires access to data, transparency and a comprehensive communication strategy, one that emphasizes transparency, rapid and considered responses, and relevance to stakeholders" and that "poor access to data inhibits users' ability to check the quality of the data used and to verify the conclusions drawn" [17] (p. 161). Thus, what has also changed in this shift is the understanding of where the boundary is drawn between who is capable of assessing the credibility of the work of the IPCC and who is not. In other words, a renegotiation has been made of when to be what and to whom throughout the process of knowledge production, especially who is referred to as part of the audience in the frontstage region and who is invited to the backstage area of knowledge production. This shift opens up the knowledge community by arguing from a collaborative perspective on the science-policy relation.

Overall, the results of the reviews performed by the PBL and the InterAcademy Council showed that the critics' claims were without any valid support. However, the review reports revealed that there are legitimate demands in the IPCC's audience for outside actors to participate in the IPCC's work by being allowed backstage and enabled to review the assessment process and the scientific data that are being used [14], cf. [22]. The argument does not stress that every organization and actor 
outside the IPCC are competent or interested enough to participate in such a review (cf. Lahsen's [73] discussion on the 'second wave of literacy'). However, the review reports raised the argument that the IPCC must acknowledge that there are competent actors in its audience who need to be able to review the backstage process, i.e., the organization's work and data, and to deliberate on the trustworthiness and credibility of the IPCC.

Thus, contrary to the point of view taken by the IPCC, the review reports reflected an understanding of the IPCC as a boundary organization that facilitates a collaborative science-policy relation with a blurred relation between sciences and policy, as well as between the backstage and frontstage of knowledge production. Credible knowledge is produced through inclusive processes that are not enclosed by the position of science per se. This means that to determine whether an organization such as the IPCC is trustworthy, the process must be reviewed not only by internal reviewers within the scientific community, but also by actors outside of science and the IPCC, i.e., actors in the audience who are faced with the decision of whether to trust the IPCC (cf. [3,4,6,44,74]). From this perspective, the process of determining the credibility of the IPCC and its assessments is a collaborative process in which multiple actors are involved (cf. [70]). To regain trust and credibility, the IPCC must, therefore, review its work process and improve its transparency.

\subsection{Friction between Perspectives on the Science-Policy Relation}

As shown in the analysis above, depending on how one understands the science-policy relation, strategies for restoring trust and credibility differ. It has also been shown that the IPCC itself and the external reviewers differed regarding the perspective from which they acted. The IPCC, through Chairman Pachauri, argued from a frontstage position to uphold the IPCC's legitimacy by using the linear ideal of creating clear demarcations between science and non-science. The chairman argued that the organization protects the scientific ideals through the design of the assessment process as a purely scientific process; he argued that the organization is a science-policy interface, but that the knowledge is to be produced backstage following a scientific (linear) ideal of how to create trustworthy, credible, relevant, and legitimate knowledge. Conversely, we have the external reviewers, who argued that this linear strategy is not feasible for upholding the IPCC's trustworthiness in the collaborative knowledge community that characterizes climate science today. Their argument continues by stating that the IPCC needs to review and embrace its hybrid qualities and collaborative capacities by renegotiating the question of when to be what and to whom and offer some backstage access to new actors who are now seated in their audience, if the IPCC is to be able to produce trustworthy, credible, relevant, and legitimate knowledge.

In summation, these ongoing discussions on how to best organize knowledge production in the IPCC to constructively balance the science-policy relation is a discussion about epistemic ideals and legitimate knowledge systems. Thus, having opposing discussants drawing from different perspectives in the landscape of tensions at the science-policy boundary risks the creation of misunderstandings (cf. $[4,8]$ ), which could make it difficult to restore a loss of trust. This difficulty is emphasized by Beck [17] (p. 168) in the case of IPCC and Climategate; she reaches the following conclusion:

By addressing the symptoms (lack of information and communication) rather than the underlying causes (lack of public accountability and transparency), the IPCC leadership is failing to adequately address the problem of restoring expert credibility. / - / As the IAC [InterAcademy Council] and PBL reviews show, public transparency and accountability do not necessarily undermine but, on the contrary, help to create public trust in climate experts.

Beck points to the impossibility of restoring a loss of trust in the IPCC by shielding the organization from the rest of society and by arguing frontstage for the legitimacy of their experts and the sovereignty of science. This impossibility is also evident in the IPCC's response to the review reports, where it became difficult to balance the science-policy relation throughout the process of knowledge production by continuing to strictly argue from a linear understanding of the science-policy relation. Instead, as a 
response to the review reports, the IPCC made a change in how they balanced science and policy and opened up a more inclusive view on who is to participate in determining the IPCC's trustworthiness and how the organization needs to be organized to involve all relevant actors in this process.

The InterAcademy Council [68] presented their report at the 32nd Session of the IPCC in October 2010. "At this Session, the Panel agreed to immediately implement several recommendations of the InterAcademy Council (IAC) Review of the Processes and Procedures of the IPCC. On others, the Panel / . . / formed Task Groups to undertake further work with a view to completion at its next Session, considering the guidance from the IAC" [69] (p. 5). The four Task Groups covered the IPCC's (i) procedures, (ii) governance and management, (iii) conflict of interest policy, and (iv) communications strategy. The focus of the Task Groups was to enhance the transparency of the IPCC, i.e., to enhance the processes and procedures in ways that allowed both those participating in them and those in the IPCC's audience to follow and review what the IPCC is doing.

The revisions to the IPCC's processes and procedures that followed the Task Groups' work did not change who is to be involved in the IPCC's assessment process. This task is still performed in the backstage regions of the IPCC, and is only open to world-leading climate scientists (e.g., [75-77]). However, the revision prompted the resetting of the frontstage of the IPCC, with the intention of becoming more transparent by presenting the assessment process in new ways and making it possible for a larger group of the IPCC's audience to have enough insight into the process to better determine whether the IPCC's processes and procedures are to be understood as trustworthy, credible, legitimate, and policy-relevant. Thus, even though the IPCC still refers to the assessment process as relying on a clear division of labor between science and policy, the IPCC acknowledged and started to adapt to the review reports' argument that there are competent actors outside of the IPCC who need to be able to review the organization's work, trustworthiness, and credibility.

\section{Conclusions}

As noted in the theoretical framework above, the idea of how the science-policy relation should be organized (frontstage self-presentation) and how it is actually organized (backstage practice) do not always coincide. This study focuses on the normative ideas of how to balance the relation between science and policy that were expressed throughout Climategate and guided the IPCC in their management of the crises. Through its analysis, the study has shown that different and sometimes conflicting ideals of how to balance science and policy coexist and interact, a finding that reveals an additional layer of tension in the social landscape at the boundary between science and policy (cf. [8]).

By revisiting the discussions on the credibility, relevance, and legitimacy of the IPCC following Climategate, two strategies on how to constructively balance science and policy were revealed. The first strategy, argued for by the IPCC, was to improve the IPCC's communication strategy to strengthen the linear relation between the organization and the rest of society. The second strategy, argued for by the review reports, was to review the IPCC's work process and improve their organizational transparency to allow for relational and collaborative knowledge production and review processes. The study further shows how the IPCC, in response to the recommendations made by the review reports, opened up to a more flexible understanding of how to balance the science-policy relation. This change allowed the IPCC to start thinking about the possibility of including both a linear and a collaborative science-policy relation in different parts of its work process. Thus, through its analysis, this study has shown how the ideas about what an effective science-policy relation is and the relations between these ideas are important as they shape the framework within which practical decisions are made on how to organize the production of knowledge and enable policy decisions, especially those that focus on when to be what and to whom (cf. [8]).

The empirical findings of this study support Parker and Crona's [8] theoretical description of the landscape of tensions at the boundary between science and policy. Through its analysis, this study also adds to the theory by showing how, instead of being understood as mutually excluding, the ideals of linear and collaborative science-policy relations exist in parallel, thus creating one of 
the tensions that needs to be navigated at the science-policy boundary throughout the process of knowledge production. In addition, by combining this theoretical perspective with Hilgartner's [59] notion of the frontstage and backstage of science, the study offers a suggestion for and provides an example of how to empirically explore this tension in both time (throughout the process of knowledge production) and space (in and between different social practices).

By combining the theoretical perspectives of the landscape of tensions [8] and the frontstage and backstage of science [59], this study suggests an analytical way forward to continue the unpacking of the black-boxing of knowledge that is taking place thorough the IPCC's assessment process (cf. [78]). By focusing on the events of Climategate, including the criticism of the IPCC's AR4, this study has explored a restricted and special time in the IPCC's history of attempting to create constructive relations between science and policy. As such, this study is by no means to be seen as an exhaustive analysis of this still ongoing process of creating constructive and efficient science-policy relations. Instead, this study is to be seen as an attempt to offer a new analytical entrance point to an already well-studied empirical case to allow for new ways forward in the provision of knowledge that supports the constructive relations between science and policy for the creation of societal change towards a sustainable future.

However, by learning from past experiences, this study contributes empirically informed knowledge on the challenge of balancing different expectations for the relation between science and policy in the process of creating trustworthy knowledge and policy decisions for a sustainable future. For boundary organizations to have a chance to impact policy discussions, reflexivity about the present epistemic ideals and legitimate knowledge systems are of major importance. For a boundary organization to determine relevant strategies to gain trust and credibility, it is not necessarily enough to unreflectively improve upon what has already been done. Instead, determining relevant strategies on how to balance science and policy to gain trust requires a boundary organization to act on different and changing expectations that are placed on the organization at different times. Thus, due to different expectations about how science and policy should be related to produce credible, legitimate, and policy-relevant knowledge, establishing constructive relations means creating flexibility for different strategies over time and in relation to different actors, such as the general public, stakeholders, and policy actors.

Funding: This research was funded by the Swedish Research Council Formas, grant number 2016-00545.

Acknowledgments: The article was partially written while working as a visiting researcher at the Environmental Policy Group, Wageningen University, The Netherlands. I would like to thank the Environmental Policy Group for hosting me. A special thanks to Aarti Gupta, Wageningen University, The Netherlands, as well as to Monika Berg and Rolf Lidskog, Örebro University, Sweden, for their comments on earlier drafts of this article.

Conflicts of Interest: The author declares no conflict of interest. The funders had no role in the design of the study; in the collection, analyses, or interpretation of data; in the writing of the manuscript, or in the decision to publish the results.

\section{References}

1. Sundqvist, G.; Gasper, D.; St. Clair, A.L.; Hermansen, E.A.T.; Yearly, S.; Øvstebø, I.; Wynne, B. One world or two? Science-policy interactions in the climate filed. Crit. Policy Stud. 2018, 12, 448-468. [CrossRef]

2. Weingart, P. Scientific expertise and political accountability: Paradoxes of science in politics. Sci. Public Policy 1999, 26, 151-161. [CrossRef]

3. Cash, D.; Clark, W.C.; Alcock, F.; Dickson, N.M.; Eckley, N.; Guston, D.H.; Jäger, J.; Mitchell, R.B. Knowledge systems for sustainable development. Proc. Natl. Acad. Sci. USA 2003, 100, 8086-8091. [CrossRef]

4. Heink, U.; Marquard, E.; Heubach, K.; Jax, K.; Hugel, C.; Neßhöver, C.; Neumann, R.K.; Paulsch, A.; Tilch, S.; Timaeus, J.; et al. Conceptualizing credibility, relevance and legitimacy for evaluating the effectiveness of science-policy interfaces: Challenges and opportunities. Sci. Public Policy 2015, 42, 676-689. [CrossRef]

5. Beck, S. Moving beyond the linear model of expertise? IPCC and the test of adaption. Regul. Environ. Chang. 2011, 11, 297-306. [CrossRef] 
6. Clark, W.C.; Mitchell, R.; Cash, D.; Alcock, F. Information as Influence: How Institutions Mediate the Impact of Scientific Assessments on Global Environmental Affairs; KSG Working Papers Series RWP02-044; Research Administration Office: Cambridge, MA, USA, 2002.

7. Koetz, T.; Farrell, K.N.; Bridgewater, P. Building better science-policy interfaces for international environmental governance: Assessing potential within the Intergovernmental platform for biodiversity and ecosystem services. Int. Environ. Agreem. 2012, 12, 1-21. [CrossRef]

8. Parker, J.; Crona, B. On being all things to all people: Boundary organizations and the contemporary research university. Soc. Stud. Sci. 2012, 42, 262-289. [CrossRef]

9. Jasanoff, S. Designs of Nature: Science and Democracy in Europe and the United States; Princeton University Press: Princeton, NJ, USA, 2005.

10. Lidskog, R.; Sundqvist, G. When Does Science Matter? International Relations Meets Science and Technology Studies. Glob. Environ. Politics 2015, 15, 1-20. [CrossRef]

11. Pielke, R. The Honest Broker. Making Sense of Science in Policy and Politics; Cambridge University Press: Cambridge, UK, 2007.

12. Haas, P.M.; Stevens, C. Organized Science, Usable Knowledge and Multilateral Environmental Governance. In Governing the Air; Lidskog, R., Sundqvist, G., Eds.; MIT Press: Cambridge, MA, USA, 2011; pp. 125-161.

13. Berg, M.; Lidskog, R. Deliberative democracy meets democratised science: A deliberative systems approach to global environmental governance. Environ. Politics 2018, 27, 1-20. [CrossRef]

14. Grundmann, R. 'Climategate' and The Scientific Ethos. Sci. Technol. Hum. Values 2011, 38, 67-93. [CrossRef]

15. Skrydstrup, M. Tricked or troubled natures? How to make sense of 'climategate'. Environ. Sci. Policy 2013, 28, 92-99. [CrossRef]

16. Schiermeier, Q. Few Fishy Facts Found in Climate Report. Nature 2010, 466, 170. [CrossRef] [PubMed]

17. Beck, S. Between Tribalism and Trust: The IPCC Under the 'Public Microscope'. Nat. Cult. 2012, 7, 151-173. [CrossRef]

18. Cogley, G.J.; Kargel, J.A.; Kaser, G.; van der Veen, C.J. Tracking the source of glacier misinformation. Science 2010, 327, 522. [CrossRef]

19. Netherlands Environmental Assessment Agency. Assessing an IPCC Assessment. An Analysis of Statements on Projected Regional Impacts in the 2007 Report; Netherlands Environmental Assessment Agency: The Hague, The Netherlands, 2010.

20. Pearce, F. The Climate Files: The Battle for the Truth about Global Warming; Guardian Books: London, UK, 2010.

21. Schiermeier, Q. Glacier estimate is on thin ice. Nature 2010, 463, 276-277. [CrossRef]

22. Lahsen, M. Climategate: The role of the social sciences. Clim. Chang. 2013, 119, 547-558. [CrossRef]

23. Beck, S. Case B What Does 'Climategate' Tell Us about Public Knowledge Controversies. In Environmental Expertise. Connecting Science, Policy, and Society; Turnhout, E., Tuinstrqa, W., Halffman, W., Eds.; Cambridge University Press: Cambridge, UK, 2019.

24. Agrawala, S. Context and early origins of the intergovernmental panel on climate change. Clim. Chang. 1998, 39, 605-620. [CrossRef]

25. About the IPCC. Available online: https://www.ipcc.ch/about/ (accessed on 20 August 2019).

26. Gustafsson, K.M.; Lidskog, R. Boundary organizations and environmental governance: Performance, institutional design, and conceptual development. Clim. Risk Manag. 2018, 19, 1-11. [CrossRef]

27. Hume, M.; Mahony, M. Climate change: What do we know about the IPCC? Prog. Phys. Geogr. 2010, 34, 705-718.

28. Siebenhüner, B. The changing role of nation states in international environmental assessments-The case of the IPCC. Glob. Environ. Chang. 2003, 13, 113-123. [CrossRef]

29. Hughes, H.R.; Paterson, M. Narrowing the Climate Field: The Symbolic Power of Authors in the IPCC's Assessment of Mitigation. Rev. Policy Res. 2017, 34, 744-765. [CrossRef]

30. Jasanoff, S.; Wynne, B. Science and Decisionmaking. In Human Choices \& Climate Change. The Societal Framework; Rayner, S., Malone, E.L., Eds.; Battelle Press: Columbus, OH, USA, 1998; Volume 1, pp. 1-87.

31. Miller, C.A. Climate Sciences and the Making of Global Political Order. In States of Knowledge: The Co-Production of Science and Social Order; Jasanoff, S., Ed.; Routledge: London, UK, 2004; pp. 46-66.

32. Berg, M.; Lidskog, R. Pathways to deliberative capacity: The role of the IPCC. Clim. Chang. 2018, 148, 11-24. [CrossRef] 
33. Pasgaard, M.; Dalsgaard, B.; Maruyama, P.K.; Sandel, B.; Strange, N. Geographical imbalances and divides in the scientific production of climate change knowledge. Glob. Environ. Chang. 2015, 35, 279-288. [CrossRef]

34. Corbera, E.; Calvet-Mir, L.; Hughes, H.; Paterson, M. Patterns of authorship in the IPCC Working Group III report. Nat. Clim. Chang. 2015, 6, 94-100. [CrossRef]

35. Ford, J.D.; Cameron, L.; Rubis, J.; Maillet, M.; Nakashima, D.; Willox, A.C.; Pearce, T. Including indigenous knowledge and experience in IPCC assessment reports. Nat. Clim. Chang. 2012, 6, 349-353. [CrossRef]

36. Ford, J.D.; Vanderbilt, W.; Berrang-Ford, L. Authorship in IPCC AR5 and its implications for content: Climate change and Indigenous populations in WGII. Clim. Chang. 2012, 113, 201-213. [CrossRef]

37. Obermeister, N. From dichotomy to duality: Addressing interdisciplinary epistemological barriers to inclusive knowledge governance in global environmental assessments. Environ. Sci. Policy 2017, 68, 80-86. [CrossRef]

38. Cash, D.; Clark, W.C.; Alcock, F.; Dickson, N.M.; Eckley, N.; Jäger, J. Salience, Credibility, Legitimacy and Boundaries: Linking Research, Assessment and Decision Making; KSG Working Papers Series RWP02-046; Research Administration Office: Cambridge, MA, USA, 2002.

39. Haas, P.M. When does power listen to truth? A constructivist approach to the policy process. J. Eur. Public Policy 2004, 11, 569-592. [CrossRef]

40. Humphreys, D. Working across boundaries: Science-policy interfaces and international forest politics. J. Integr. Environ. Sci. 2009, 6, 163-174. [CrossRef]

41. Hoppe, R.; Wesselink, A. Comparing the role of boundary organizations in the governance of climate change in the EU member states. Environ. Sci. Policy 2014, 44, 73-85. [CrossRef]

42. Ourbak, T.; Laurence, T. Changing the game: The Paris Agreement and the role of scientific communities. Clim. Policy 2017, 17, 819-824. [CrossRef]

43. The Nobel Peace Prize 2007. Available online: https://www.nobelprize.org/nobel_prizes/peace/laureates/2007/ (accessed on 8 March 2018).

44. Jahansoozi, J. Organization-stakeholder relationships: Exploring trust and transparency. J. Manag. Dev. 2006, 25, 942-955. [CrossRef]

45. Lacey, J.; Howden, M.; Cvitanovic, C.; Colvin, R.M. Understanding and managing trust at the climate science-policy interface. Nat. Clim. Chang. 2018, 8, 22-28. [CrossRef]

46. Goodwin, J.; Dahlstrom, M.F. Communication strategies for earning trust in climate change debates. WIREs Clim. Chang. 2014, 5, 151-160. [CrossRef]

47. Lucas, C.; Leith, P.; Davison, A. How climate change research undermines trust in everyday life: A review. WIREs Clim. Chang. 2015, 6, 79-91. [CrossRef]

48. Curry, J. Opinion: Can scientists rebuild the public trust in climate science? Physics Today, 24 February 2010.

49. Leiserowitz, A.A.; Maibach, E.W.; Roser-Renouf, C.; Smith, N.; Dawson, E. Climategate, Public Opinion, and the Loss of Trust. Am. Behav. Sci. 2012, 57, 818-837. [CrossRef]

50. Guston, D.H. Stabilizing the boundary between US politics and science: The role of the office of technology transfer as a boundary organization. Soc. Stud. Sci. 1999, 29, 87-111. [CrossRef]

51. Guston, D.H. Between Politics and Science. Assuring the Integrity and Productivity of Research; Cambridge University Press: Cambridge, UK, 2000.

52. Guston, D.H. Boundary organizations in environmental policy and science: An introduction. Sci. Technol. Hum. Values 2001, 26, 399-408. [CrossRef]

53. Miller, C.A. Hybrid management: Boundary organizations, science policy, and environmental governance in the climate regime. Sci. Technol. Hum. Values 2001, 26, 478-500. [CrossRef]

54. Mørk, B.E.; Hoholm, T.; Maaninen-Olsson, E.; Aanestad, M. Changing practice through boundary organizing: A case from medical R\&D. Hum. Relat. 2012, 65, 263-288.

55. Gustafsson, K.M.; Wolf, S.A.; Agrawal., A.A. Science-Policy-Practice Interfaces: Emergent knowledge and monarch butterfly conservation. Environ. Policy Gov. 2017, 27, 521-533. [CrossRef]

56. Jasanoff, S. The Idiom of Co-Production. In States of Knowledge: The Co-Production of Science and Social Order; Jasanoff., S., Ed.; Routledge: London, UK, 2004; pp. 1-12.

57. Nowotny, H.; Scott, P.; Gibbons, M. Re-Thinking Science. Knowledge and the Public in an Age of Uncertainty; Polity Press: Cambridge, UK, 2001. 
58. Wynne, B. Risk as Globalizing 'Democratic' Discourse? Framing Subjects and Citizens. In Science and Citizens: Globalization and the Challenge of Engagement; Leach, M., Scoones, I., Wynne, B., Eds.; Zed Books: London, UK, 2005; pp. 66-82.

59. Hilgartner, S. Science on Stage. Expert Advice as Public Drama; Stanford University Press: Stanford, CA, USA, 2000.

60. Latour, B. From the World of Science to the World of Research? Science 1998, 280, 208-209. [CrossRef]

61. White, D.D.; Corley, E.A.; White, M.S. Water managers' perceptions of the science-policy interface in Phoenix Arizona: Implications for an emerging boundary organization. Soc. Nat. Res. 2008, 21, 230-243. [CrossRef]

62. White, D.D.; Wutich, A.; Larson, K.L.; Gober, P.; Lant, T.; Senneville, C. Credibility, salience, and legitimacy of boundary objects: Water mangers' assessment of a simulation model in an immersive decision theater. Sci. Publ. Policy 2011, 37, 219-232. [CrossRef]

63. Keating, T.J. Lessons from the recent history of the health effects institute. Sci. Technol. Hum. Value 2001, 26, 409-430. [CrossRef]

64. Boezeman, D.; Vink, M.; Leroy, P. The Dutch delta committee as a boundary organization. Environ. Sci. Policy 2013, 27, 162-171. [CrossRef]

65. House of Commons Science and Technology Committee, P.o.t. UK. The Disclosure of Climate Data from the Climatic Research Unit at the University of East Anglia; House of Commons Science and Technology Committee: London, UK, 2010.

66. Oxburgh, R.; Davies, H.; Emanuel, K.; Graumlich, L.; Hand, D.; Huppert, H.; Kelly, M. Report of the International Panel Set up by the University of East Anglia to Examine the Research of the Climatic Research Unit; University of East Anglia: Norwich, UK, 2010.

67. Myths vs. Facts: Denial of Petitions for Reconsideration of the Endangerment and Cause or Contribute Findings for Greenhouse Gases under Section 202(a) of the Clean Air Act. Available online: https:/www.epa.gov/ghgemissions/myths-vs-facts-denial-petitions-reconsideration-endangermentand-cause-or-contribute (assessed on 5 February 2018).

68. InterAcademy Council. Climate Change Assessments: Review of the Processes and Procedures of the IPCC; InterAcademy Council: Amsterdam, The Netherlands, 2010.

69. The Intergovernmental Panel on Climate Change. Report of the 32nd Session of the IPCC; The Intergovernmental Panel on Climate Change: Busan, Korea, 2010.

70. Hajer, M.A. A media storm in the world risk society: Enacting scientific authority in the IPCC controversy (2009-2010). Crit. Policy Stud. 2012, 6, 452-464. [CrossRef]

71. Ritzer, D. IPCC's problem at the top. Climate Etc., 11 July 2011.

72. Collins, H.M.; Evans, R. Rethinking Expertise; The University of Chicago Press: Chicago, IL, USA, 2007.

73. Lahsen, M. Climategate and the virtue of the scientific community: An editorial commentary on the Maibach etal. and Grundmann opinion articles. WIREs Clim. Chang. 2012, 3, 279-280.

74. Clark, W.C.; Mitchell, R.B.; Cash, D.W. Evaluating the Influence of Global Environmetnal Assessments. In Global Environmental Assessments; Mitchell, E.B., Clark, W.C., Cash, D.W., Dickson, N.M., Eds.; MIT Press: Cambridge, MA, USA, 2006; pp. 1-28.

75. The Intergovernmental Panel on Climate Change. Report of the 40th Session of the IPCC; The Intergovernmental Panel on Climate Change: Copenhagen, Denmark, 2014.

76. Preparing Reports. Available online: https://www.ipcc.ch/about/preparingreports/ (accessed on 11 October 2019).

77. Engage with the IPCC. Available online: https://www.ipcc.ch/about/engage_with_the_ipcc/ (accessed on 11 October 2019).

78. Latour, B. Pandora's Hope: Essays on the Reality of Science Studies; Harvard University Press: Cambridge, MA, USA, 1999.

(C) 2019 by the author. Licensee MDPI, Basel, Switzerland. This article is an open access article distributed under the terms and conditions of the Creative Commons Attribution (CC BY) license (http://creativecommons.org/licenses/by/4.0/). 